\title{
The international political economy of agriculture and food: An introduction Alessandro Bonanno and Lawrence Busch
}

In his illustration of the virtues of neoliberalism and the functioning of the free market, Friedrich von Hayek (2011[1960]; 2007[1944]) denounces the perils associated with attempts to politically direct the economy. Referring to politically selected economic objectives and measures as "intelligent design," Hayek contends that they can never be replacements for the highly desirable solutions offered by the autonomous functioning of the market. Political plans of any type, he contends, need to be eliminated from the managing of the economy. Accordingly, for Hayek and likeminded neoliberals, political economy should be confined to nothing more than the free functioning of the market. This neoliberal position stands in sharp contrast to the manner in which the political economy of agri-food has been interpreted and evolved for virtually the entire modern era and, certainly, throughout the 20th Century. Keynesian, radical, socialist, social democratic, but also beginning of the century laissez-faire approaches have interpreted and managed agriculture and food in terms of the interplay of a variety of factors pertaining to the economic, social, cultural, political and geopolitical spheres. These and other factors have been considered central in the directing of agri-food development and the achievement of the specific goals assigned to this sector.

In this context, for the greatest part of the 20th Century, agriculture and the production and distribution of food around the world were highly planned activities supported and coordinated by the intervention of the nation-state. Continuing practices initiated in previous centuries, the capitalist nation-states of advanced countries directed the organization of agriculture and food not only in terms of the economic growth and social stability of the sector, but, above all, in terms of the overall balanced development of the entire society. The production of affordable food for the growing urban lower and middle classes, the controlled migration of agricultural labor to manufacturing jobs and cities and the creation of a reliable system for the production of food for the domestic market and security became the period's fundamental objectives of virtually all nations. Indeed, both democratic and authoritarian regimes understood that cheap food limited social unrest. The insistence on the use 
of a social planning approach found support in theory and practice. The popularity of Keynesian economic theory justified state-sponsored deficit spending as a system to stimulate demand and reignite economic growth. Simultaneously, the acceptance of Henry Ford's (1988[1926]) industrial policy of high wages was central for the development of mass consumption, employment growth, social stability and the enhancement of profit. As pointed out by Antonio Gramsci (2011[1945]) in his classical essay "Americanism and Fordism," state intervention in the economy was complemented by the promotion of cultural patterns that provided legitimacy to state planning and regulation.

The political economy of agriculture of this Fordist era featured state promoted intervention in a variety of areas, including land redistribution, infrastructure building, publicly sponsored research and development, and price control and commodity programs. The declared goal was to increase production and productivity in order to generate abundant food to feed the growing domestic and world population. This overt objective was to be achieved through the enhanced use of machines, chemicals, improved plant varieties and the application of productivist industrial plans. Latent objectives included the containment of labor reproduction cost and the establishment of pacified labor relations through the availability of affordable consumer goods. Geopolitically, food remained an important tool in the shaping of international relations. While class differences and inequality continued to be sharp and the growth of agricultural regions occurred at a lower rate than their urban counterparts, the objective of ensuring rural communities' social stability and sustainability featured centrally on the agendas of many governments. Reacting to the Fordist high level of state intervention in agriculture, the neoliberal theorist Milton Friedman (1982[1962]:181) argued that agricultural special interests controlled the US Congress and that rural districts were overrepresented in the electoral system. He saw this as distorting prices such that the free market could not work according to the model. Far from representing reality, this view concealed the significant socio-economic differences within agri-food and the struggle of small farm holders and farmworkers to keep their farms and jobs vis-à-vis a process of structural and productive concentration.

In less developed countries of the South, Fordism translated primarily into the application of modernization policies to peasant-dominated sectors. Legitimized by functionalist arguments about the necessity to apply the US model of development (Parsons 1971; Rostow 1960), state intervention in agriculture took a form that favored corporate investment and presence, the outflow of wealth and the exploitation of natural resources and labor. Simultaneously, however, modernization also involved measures that favored land redistribution, reclamation and 
irrigation programs, infrastructure building and schemes in support of small farm holders and peasant agriculture. Facing mounting contradictions and a legitimation crisis, many countries in the South experimented with import substitution policies whose results, however, fell short of intended outcomes and often increased economic and political dependency.

In the late 1970s, limited corporate profitability and the fiscal crisis that affected virtually all major nation-states ushered the final crisis of Fordism. Propelled by the strong political movements that led to the elections of Ronald Reagan in the United States and Margaret Thatcher in Britain, neoliberalism emerged as the new dominant ideology and political economic strategy. Finding strength in the crisis and eventual collapse of the Soviet system, the weakness of the political left and unions, arguments about the ineffectiveness and inefficiency of state intervention and claims about the neutrality and benign nature of the market, neoliberalism offered an appealing solution to global social and economic problems. Declaring the end of the historical contraposition between capitalism and socialism, Francis Fukuyama (1992) stressed that free market capitalism was the only possible way to govern the world. Lacking an alternative vision, left leaning theorists and political groups yielded to the hegemonic power of neoliberalism. Writing from a leftist position, Thomas Friedman $(1999 ; 2005)$ lauded the consequences of the application of neoliberalism at the global scale by contending that it flattened historical differences and obstacles and allowed large segments of previously marginalized groups to benefit from the growth of neoliberal globalization. Relinquishing historically held objectives, parties of the left moved to centrist positions. In the United States, the Democratic Party led by President Clinton restructured and downsized the welfare system and contributed to the establishment of the so-called Washington Consensus: a convergence of interests in support of neoliberal views of political economy.

The reduction of trade barriers and nation-state regulations promoted the creation of networks of production and consumption that feature spatial decentralization, global organization and economic concentration. Supported by the dominant view of the desirability of free market solutions, a selected number of large corporations established quasimonopolistic control of key commodity markets. Similarly, large food retailers began to control the distribution industry and exercise power over production processes as well. This shift was aided by the growth of information technology and containerization that opened up numerous new commercial options. State regulation was replaced by third party programs that privatized control, imposed production strategies and prescribed behavior to producers, hired labor and consumers worldwide. The 
enhanced global circulation of commodities and capital became accompanied by the establishment of stronger forms of control and exploitation of labor. The creation of precarious and poorly remunerated jobs was implemented through, and justified by, the desirability of higher levels of competitiveness and cost containment and the presumed convenience that the availability of these jobs entails for workers. These conditions led to the current control of wages and labor resistance through the creation of a large reserve army of labor established through the mobilization of previously untapped labor pools, production decentralization and massive processes of migration whereby the use of migrant labor is controlled through the criminalization of migratory processes and immigrant status. As debates on immigration often center on political conditions, humanitarian aspects and the suffering and resilience of immigrants, dominant discourses conceal the economic relevance of the presence of a docile and inexpensive labor force worldwide (Bonanno and Cavalcanti 2014).

Neoliberalism promoted processes that resulted in the economization of society, politics and the individual (Foucault 2004; Dean 2010; Rose 1996). The economization of society refers to processes whereby the organization of social relations is decentered from the state to the market. Market relations and profitability become the core conditions for desirable social arrangements. In this context, the distinction between society, regulated and governed by the actions of the state, and the economy, defined by the search for profit and the satisfaction of individual interests, is erased. Accordingly, market-based rationality becomes the entity that guides the regulation of society. In the economization of politics, political institutions employ "economic rationality" and operate in a corporate-like manner, transforming the search for profit into a social value and primary regulatory criterion. Simultaneously, corporations take up charges and regulate matters (such as ethics and morality) that once were the exclusive prerogative of the state (Ronen 2008). The displacement of the state as the political regulatory authority allows corporations to assert greater power in defining rules of regulation as control is shifted to those close to the problem (Busch 2014). The economization of the individual refers to processes whereby individual actors assume moral responsibility for all of their actions (responsibilization) (Ronen 2008). Dismissing structural constraints and power relations, individuals are seen as endowed with the ability to fully define their actions. And solutions to problems are increasingly assigned to the individual sphere (individualization). In this context, the organization and management of agri-food is increasingly placed in the hands of private corporate actors while solutions to problems and alternatives are shifted to the initiative of individual consumers.

Opposition to these dominant conditions and the creation of alternative 
production and consumption systems have been shaped and contained by the ideological and political power of neoliberalism. The crisis of organizations (parties and unions) that traditionally represented the working class is extended by the mobilization of the reserve army of labor and the presentation of the functioning of the market as a neutral and objective process. Simultaneously, agri-food production and distribution alternative systems (e.g., organic farming, farmer markets, civic agriculture, Slow Food and more), while otherwise successful, have been charged with reproducing elitism, failing to improve the conditions of the working class and the poor and accepting dominant values and the fundamental tenets of the very neoliberal ideology that they try to counter. More importantly, they have been criticized for offering limited resistance to the expansion of corporate agri-food as the latter has been even often able to colonize these alternative initiatives.

Salient aspects of the political economy of agriculture and food are reviewed by the authors included in this volume. They are organized into two parts. The first presents the cases of selected countries and world regions. This geographical organization of the book is complemented by a second part that analyzes selected themes. Without claiming to be exhaustive, the selection of areas and themes is designed to provide instances of relevant features and changes that characterize agri-food. The first part of the volume opens with two chapters that illustrate examples of the evolution of agri-food in Africa and Oceania. In the opening chapter, Elizabeth Ransom analyzes the evolution of agri-food in the Southern portion of Africa. This region includes Botswana, Lesotho, Namibia, South Africa and Swaziland, whose development contends with the consequences of past colonial rule and declining access to the European market. The dual system of large export oriented farms and peasant agriculture has been impacted by the establishment of the World Trade Organization (WTO) that, along with other factors, contributed to the neoliberalization of these agricultures and the limited availability of alternative policies. The economic weakness of the large number of small units overexposes these farming sectors to climate change that often translates into both droughts and floods. Additionally, gender and racial inequality produce problems that are difficult to address. The search for regional alternative policies, Ransom concludes, appears as a locally supported solution to this region's dependence on global market forces. In the following chapter, Carmen Bain and Tamera Dandachi examine the dairy sector in New Zealand. In particular, they probe the contradictory situation of dairy in a context characterized by a neoliberal approach to environmental regulation. They contend that the image of New Zealand as an environmentally clean and ecologically pristine country has legitimized lax environmental laws and 
a voluntarist approach to environmental regulation. This limited regulation, they continue, has been instrumental in the growth of the dairy sector and international competiveness. The contradiction between a clean and environmentally sound image and the actual limited protection of the environment, the authors conclude, remains an unresolved problem that will continue to characterize the evolution of agri-food in New Zealand.

The next set of five chapters deal with agri-food in Latin America. The first of these chapters explores the case of Mexico. Francisco Martínez and Gilberto Aboites analyze the evolution of an increasingly polarized agri-food sector that is formed by an economically strong and numerically small sector of agri-food firms and a poor and numerically large small farm/peasant sector. They contend that the Fordist period in Mexico was characterized by the expansion of domestic consumption that favored the growth of agriculture and food production. Simultaneously, state support for the small farm/peasant sector allowed the persistence of a large number of small farm holders. The introduction of neoliberal policies in the 1980s and the membership in NAFTA (North American Free Trade Agreement) in the early 1990s changed this situation, fostering a restructuring of the sector and its orientation toward the production of fruits and vegetables for export. This reorientation of the sector affected the production of commodities for domestic consumption such as corn. High priced imports replaced locally produced corn, creating significant increases in the prices of basic food items and, ultimately, dissatisfaction among the local population. The authors conclude by highlighting the current contradictory conditions of Mexican agri-food whereby integration into the global market and, particularly, enhanced commercial relations with the United States are accompanied by a delegitimation of the actions of the government.

The chapter by Clara Craviotti explores the conditions of agri-food in Argentina. One of the largest word suppliers of the food-feed-energy complex, Argentina has experienced a significant process of change following the development of globalization and the insertion of the country into the new global division of labor. Technical innovations associated with deregulation and the growth of financialization, Craviotti contends, created new systems of agri-food production. Particularly relevant is the establishment of pools de siembra, or networks of production management based on contractual relations that supplanted traditional forms of production based on property in land, machines and inputs. In this new form of production, limited fixed capital is employed along with the flexible use of labor and equipment. This reorganization of agriculture has reintroduced the export-based growth model that was dominant during the immediate pre-World War II decades. As this new development model 
remains susceptible to commodity market fluctuations, it makes Argentina particularly vulnerable to market downturns. Also relevant are the environmental consequences of the extensive production of global crops, such as soya, that increase Argentina's instability and future uncertainties.

The significantly different case of Colombia is discussed in the chapter by Anouk Patel-Campillo and María del Rosario Castro Bernardini. Employing David Harvey's concept of accumulation by dispossession, the authors illustrate the evolution of social relations in agriculture, focusing on the processes of land concentration and redistribution. Patel-Campillo narrates the growth of Colombian agriculture by dividing it into three periods. The first covers the years from the post-independence era to 1960 . During this long period, efforts to distribute land to peasants and family farm holders were accompanied by processes of land consolidation in the hands of large landowners (latifundistas). This contradictory situation led to social instability that contributed to the emergence of a period of overt violent confrontations (1947-1964). The second period was characterized by the implementation of modernization and land redistribution (land reform) policies. Their failure radicalized conflict that was characterized by the emergence of armed guerrilla factions and the creation of prorural elite vigilante groups. While the escalation of violence delegitimized political processes, it also allowed the repression of peasants and farmers and the further concentration of land ownership by rural elites. The third and final period coincided with the liberalization of agricultural policies. Drug lords used land to recycle profit from their illegal trade and found in land ownership a vehicle for social legitimacy and political clout. Simultaneously, the insertion of Columbian agriculture into global networks weakened domestic food production and food imports increased dramatically. The strengthening of the power of the rural landed class and the further displacement of small farm holders and peasants define a complex and contradictory situation that can be hardly addressed by neoliberal measures.

The case of Brazil is analyzed by Josefa Salete Barbosa Cavalcanti and Evander Eloi Krone. The authors stress the continuity of the export oriented agricultural policy that has characterized Brazil since colonial times and the concomitant prominent role played by large landowners and the overt exploitation of labor. Recent decades have not altered the emphasis on export oriented policies that are mitigated by state promoted profamily farm measures and investment. The current situation sees a growth of the corporate presence in agri-food not only at the level of production but also at the level of retailing. Large supermarket chains have a firm grip on agri-food production in the country, dictating the conditions of production as well as the use of labor. Vulnerability to market fluctuations 
remains highly relevant for the family farm and peasant sectors. While contradictory, their involvement in the production of quality products for export and membership in global networks of production are seen as fundamental conditions for growth.

The fifth of this group of chapters, by Gabriela Pechlaner and Gerardo Otero, probes the effects of NAFTA on the participating countries of Mexico, Canada and the United States. These authors contend that NAFTA is an excellent example of the types of changes that resulted from the neoliberal globalization of agri-food. Original predictions, they argue, stressed that the liberalization of markets and borders would have created the homogenization of production and diets. In reality, the authors demonstrate, NAFTA has generated a "differentiated convergence" in which the most negative consequences are disproportionally experienced by Mexico, the least economically developed of the three partner countries, and by members of the lower classes. As agricultural trade has increased among these three countries, the United States has retained its hegemonic position while import dependence has increased for Mexico with significant negative consequences for local consumers. Pechlaner and Otero further contend that there has been a "class differentiated convergence" of diets featuring an increase in the consumption of meat and fruits that does not involve the lower classes. This socio-economic divergence has negative consequences not only on social inequality but also on food security and health. While the positive view of liberalization remains dominant, the authors conclude, the negative consequences of NAFTA are increasingly evident in Mexico and among the poorer social strata.

The first part of the book concludes with three chapters that discuss the agri-food sectors of countries of the advanced North. In her chapter on Japan, Kae Sekine maintains that agri-food was shaped by the country's post-World War II rapid growth. Based on the export of selected consumer goods, Japanese developmental policy assigned a complementary yet important role to agri-food. Particularly relevant was the role played by the farm sector as a reservoir of excess labor. This surplus labor eventually migrated to urban areas and was key to the development of manufacturing and the overall success of the Japanese growth model. The post-war reorganization of agri-food was based on democratic principles that stressed the importance of family farming and collective decision making. Significant changes, Sekine illustrates, occurred in the 1980s and 1990s as Japan embraced neoliberal reforms. The family farm orientation that characterized the sector was reversed in favor of the corporatization of agri-food. Deregulation policies were implemented to promote corporate investment in the hope of a revitalization of the sector. Despite this move, Japanese agri-food, the author concludes, remains much less developed 
than other economic sectors, while the corporatization of agri-food generates discontent among the rural and also general population.

The evolution of the European Union's Common Agricultural Policy, or CAP, is analyzed in the chapter by Manuel Belo Moreira. Moreira divides the development of the CAP into four periods. The first covers the first 30 years since the implementation of the CAP (1962). During this time, agri-food policy was aimed at the modernization of agriculture through a productivist approach that, however, contained strong provisions for the preservation of family farms. This latter objective was pursued through an extensive system of price support and trade protection programs. This period ended in the early 1990s as the MacSharry reform reoriented the CAP away from productivist policies toward a multifunctional view of agriculture. Central in this new orientation was the objective of rural development, which was decoupled from the expansion of production and productivity. A further reorganization of the CAP characterized the third period that began in 2003. This new period saw the decoupling of support programs from production levels and the creation of a single payment scheme. In this contest, not only rural development but also a strong pro-environment posture became features of the agri-food policy of the European Union. The fourth and current period continues the move toward the neoliberalization of agri-food that has shaped the CAP over the previous three decades. However, due to the fiscal crisis of this supranational organization, Moreira contends that a move toward the renationalization of policy and its focusing on agriculture, rather than on the environmental and rural development, will increasingly characterize the CAP.

Miren Etxezarreta, Jordi Rosell and Lourdes Viladomiu probe the development of agri-food in Spain. Among the most relevant characteristics of the evolution of the agri-food sector of Spain are its integration into the global system, the modernization of its farms and significant modifications of its labor market and structure. This rapid change has generated a current situation in which the overall importance of farming has declined significantly in terms of its contribution to the economy, employment and the quantity of farmland employed. A significant portion of this land has been redirected to other and more lucrative uses as the financialization of the sector and of the economy has contributed to this outcome and the overall reorganization of agri-food. The internationalization of production, these authors maintain, has increased the role that it plays as exporter of key commodities such as fruits, olive oil and wine, but it has also exacerbated the dualism of the local farm structure. The large farm-dominated export sector, the authors conclude, will likely continue to grow. Yet, the resilience of the family farm sector and pressure from 
urban consumers and groups for better quality agri-food products and environmentally friendly production processes will also condition future developments.

The second part of the volume opens with the chapter by Geoffrey Lawrence and Jane Dixon that discusses the role of supermarkets. The authors stress that supermarket chains are powerful transnational corporations that not only control food retailing but also food supply. In this context, supermarkets have emerged as major regulators of the agrifood system and gatekeepers of food consumption. Their actions define food choice and quality and are legitimized by the convenience that they provide to consumers. Their attention to more rigorous food standards and regulation has been instrumental to the achievement of this hegemonic position. However, through the implementation of these standards, they have been able to affect farmers and the farming sector often to the detriment of small farm holders, farmworkers, the environment and the health of consumers. Resistance to this supermarketization has forcefully emerged, as the authors document. Yet, the creation of alternative agrifood systems decreases pressure on supermarkets to respond to alternative claims and has not been an obstacle to these organizations' continuous growth. In their concluding remarks, these authors call for greater clarity in the regulation of supermarkets and, ultimately, for ways that can counter their growing concentration and power.

Often mentioned in the previous chapters as one of the major phenomena of the neoliberal global era, the financialization of agri-food is reviewed by Madeleine Fairbairn. Financialization refers, first, to the increased importance of financial capital over manufacturing and agricultural capital in the overall generation of profit and, second, to the fact that a large and growing share of profit is made through the buying and selling of financial products. In her illustration of the growth of financialization in agri-food, Fairbairn stresses that some financial products, such as derivatives, have been long standing features of the sector. Items such as contracts that establish future prices of agricultural commodities to be sold at harvest have been popular since the 19th Century. However, the financial deregulation that occurred as part of the neoliberalization of the economy changed this situation drastically, allowing the trading of financial products independently from production trends and outcomes. In this context, agri-food commodities have been transformed into assets subjected to financial trade and speculation, products that interest a large spectrum of investors and entities that are primarily used to increase shareholder value. Financialization, this author maintains, has transformed the economy into a system that is centered on the generation of shareholder returns. Financialization, Fairbairn continues, has been extended to all 
components of agri-food including supermarkets and land. In the case of supermarkets, financialization decouples investment from quality of service as supermarkets are purchased and restructured primarily to increase their resale value rather than service efficiency. Simultaneously, large food retail corporations, the author documents, have become active actors in the financial sector as they now offer financial services to consumers, such as banking, credit cards, insurance programs and home mortgages, and hold more financial assets than real assets. In the case of land, while often justified in terms of production needs and food security, its purchase as a financial asset and an item to be employed in speculative moves has become one of the major global phenomena. Fairbairn concludes by stressing the growing importance of financialization in the shaping of agri-food regimes.

In the chapter entitled "The political economy of labor relations in agriculture and food," Alessandro Bonanno discusses the recent evolution of labor relations. He contends that the 20th Century Fordist era was characterized by stable and pacified labor relations regulated by the tacit, yet effective, "management-labor accord." In this context, agricultural labor represented a fundamental factor in the increase of production that generated abundant and inexpensive food for urban dwellers and a reservoir of labor for the growth of urban manufacturing. While agricultural employment remained seasonal, more unstable and less remunerated that its urban counterpart, Fordist wealth redistribution mechanisms allowed a progressive betterment of labor's living and working conditions. Neoliberal globalization changed this situation. The author discusses this change by stressing seven relevant aspects. First, there is a flexibilization of labor relations that consists of reduced wages, precarious and unstable employment, enhanced exploitation and the political weakness of agri-food workers. Second, the mobilization of a large reserve army of labor allows the enhanced control of labor's wages and claims. Through decentralization of production and global sourcing, distant labor pools are placed in direct competition with each other resulting in the creation of a docile and inexpensive labor force. Third, similar results are accomplished through the use of immigrant labor. As neoliberalization promotes the free circulation of goods and services, labor mobility remains highly controlled mostly through political mechanisms (i.e., citizenship, residency, work permits and work programs). Moreover, the criminalization of immigrant labor further allows the control of this component of the global reserve army of labor. Fourth, agri-food labor is feminized. The use of female labor is promoted not only in terms of the use of inexpensive workers but also in terms of a discourse that legitimizes labor exploitation. The presentation of flexible labor as "convenient" for women conceals 
the many disadvantages associated with this form of employment. Fifth, the development of third party production contracts allows firms to circumvent labor laws and regulations and further the exploitation of labor. Sixth, the crisis of labor unions weakens resistance. This crisis, it is argued, is not only the result of a deliberate corporate attack on unions but also the result of ineffective union strategies. Finally, the author contends, resistance centers on spheres that do not consider labor as a central component. While successful in some instances, overall, these efforts have not been able to halt the power of corporate agri-food and the worsening of the conditions of labor.

In the following chapter, and focusing on the case of Italy, Maria Fonte and Ivan Cucco address the theme of alternative agri-food movements. The authors highlight the characteristics of the development of agriculture in Italy since the immediate post-World War II years, stressing the changes in objectives of agri-food movements. They contend that Fordist labor-based, union-led movements were replaced by consumer centered, quality oriented organizations in the post-Fordist neoliberal globalization era. In particular, they review the objectives, discourses and actions of four movements: Campagna Amica, the organic movement, Slow Food and the Solidarity Purchasing Group movement. Campagna Amica, or CA, is an organization of the Coltivatori Diretti, a post-World War II Christian Democratic Party (CD) directed farmer organization. During the Cold War era, CD continuously ruled Italy. However, it dissolved, along with other era political parties, after the fall of the Communist bloc and the end of the Cold War. A strong supporter of modernization and productivist strategies, CA followed changes in EU policy to transform itself into a fervent advocate of quality, made-in-Italy agri-food products. This combination of quality production and protectionism has allowed CA to achieve significant economic visibility, as its products are now widely available through major supermarket chains. The organic movement, the authors contend, counted on the participation of a number of small groups that contributed to the establishment of an important, yet fragmented, movement. In the early 1990s, it reached a significant level of popularity, propelled by the introduction of pro-organic EU legislation. This recognition, the authors continue, translated into a "conventionalization" of the organic sector that was co-opted by mainstream agri-food and its products sold by corporate retailers. Slow Food is described as a complex social movement with significant clout in Italian food politics. Born out of the dissolution of Cold War politics and resistance to the expansion of corporate fast-food, Slow Food became the symbol of culturally rich and locally oriented food production and consumption. Stressing the convivial dimension of food, this movement does not necessarily oppose 
capitalism and corporate food, but it struggles for the recognition, persistence and growth of artisan food in all its forms and varieties. Solidarity Purchasing Groups (or GAS as per the Italian acronym) emerged as a response to the conventionalization of other alternative movements and the growth of globalization. Inspired by the international civic agriculture movement, the GAS movement grew dramatically from its first appearance in the mid-1990s. Its horizontal form of coordination contemplates the creation of direct contacts between producers and consumers, framed by a discourse that emphasizes the relevance of the local, agro-ecological sustainability, civic responsibility and solidarity. The authors conclude by stressing that the significant presence of alternative agri-food movements in Italy is partially a by-product of the niche- and local-production-based historical development of this sector and country. They further indicate that the conventionalization of these movements has significantly limited the construction of effective alternatives, but the emergence of GAS represents a likely alteration of this pattern.

In their chapter entitled "Animal welfare: The challenges of implementing a common legislation in Europe," Mara Miele, Bettina Bock and Lummina Horlings discuss the implementation of animal welfare legislation in the European Union. Paying particular attention to the implications that it has in terms of the economization of values in agri-food, they stress that EU directives that support animal welfare have been introduced to address growing concerns voiced by pro-animal welfare organizations and the general public. Through a multi-nation study that focuses on the case of the Netherlands, the chapter documents the conditions that determine differences in the implementation of EU legislation. It also stresses that the implementation of value oriented legislation is framed in a context of marketization (economization) of agri-food products whereby animal welfare is transformed into a factor that promotes the commercialization of agri-food products. Simultaneously, the case of the Netherlands is described as an example of a new form of governamentality in which "best practices" are implemented by a private-public expert group. In this context, the state remains the political regulatory authority. Yet, it is part of a neo-corporatist collaboration that includes a variety of stakeholders such as agro-business, researchers and civic organizations.

In their chapter, Leland Glenna, Barbara Brandl and Kristal Jones tackle the issue of the international political economy of research and development (R\&D). They contend that throughout the 20th Century, state directed $R \& D$ was an irreplaceable component of the evolution of agri-food, the introduction of technical innovations and increases in food production and farm productivity. In recent decades, and because of the adoption of neoliberal policies, stagnant public expenditures and the 
concomitant increase of private investment created conditions that are viewed as threatening to the ability to produce food and the food needs of developing countries and regions. In particular, the authors show that reliance of private-sector funding in advanced countries fosters research on crops that are relevant to agri-food corporations but do not necessarily address food needs at the world level. While differences exist among major developed countries, the neoliberalization of $R \& D$ is a common trend. In emerging countries, however, public investment in R\&D is growing as a result of the adopted neo-Fordist postures. Yet, even in these countries, the emphasis on commercially relevant crops generates doubts as to the adequacy of this solution. The authors conclude by stressing the importance of publicly directed $\mathrm{R} \& \mathrm{D}$ that could generate a more environmentally sound, just and sustainable agri-food development.

In the final chapter of this volume, Carolyn Sachs probes the very important issue of the role of women in agri-food. She documents that women provide the majority of labor in contemporary agriculture in many regions of the world. This is an important fact given the common understanding of agriculture as a "male" sector. Discussing regions of the global South, Sachs underscores the importance of the role of women in the production of export crops, as the flexibilization of female labor is one of the most decisive factors in the organization of this type of production. Precarious employment, low pay, harassment and sexual violence characterize the lives of these workers. Female labor also constitutes an important component of migrant labor that from regions of the global South is displaced to work in rich nations of the North. Its immigrant and female statuses make it the most vulnerable segment of the agri-food labor structure. In the case of family farms, Sachs continues, the difficulties that this sector encounters as corporate agriculture expands are particularly felt by women. The proportion of women that operate family farms has significantly increased in recent years along with these farms' weak economic situation. Despite these adverse conditions, Sachs concludes, women have emerged as a formidable force in global struggles for a more democratic and sustainable agri-food.

\section{REFERENCES}

Bonanno, Alessandro and Josefa Salete Barbosa Cavalcanti (eds.). 2014. Labor Relations in Globalized Food. Bingley, UK: Emerald Publishing.

Busch, Lawrence. 2014. "How Neoliberal Myths Endanger Democracy and Open New Avenues for Democratic Action.” Pp. 32-51 in Steven A. Wolf and Alessandro Bonanno (eds.) The Neoliberal Regime in the Agri-food Sector: Crisis, Resilience and Restructuring. New York: Routledge. 
Dean, Mitchell M. 2010. Governamentality: Power and Rule in Modern Society. London: Sage.

Ford, Henry. 1988[1926]. Today and Tomorrow. New York: Productivity Press.

Foucault, Michel. 2004. The Birth of Biopolitics. New York: Picador.

Friedman, Milton. 1982[1962]. Capitalism and Freedom. Chicago: University of Chicago Press.

Friedman, Thomas. 1999. The Lexus and the Olive Tree. New York: Anchor Books.

Friedman, Thomas. 2005. The World Is Flat: A Brief History of the Globalized World in the Twentieth-First Century. New York: Allen Lane.

Fukuyama, Francis. 1992. The End of History and the Last Man. New York: The Free Press.

Gramsci, Antonio. 2011[1945]. Prison Notebooks. Translated by Joseph A. Buttigieg. New York: Columbia University Press.

Hayek, Fredrick A. von. 2007[1944]. The Road to Serfdom. Chicago: University of Chicago Press.

Hayek, Fredrick A. von. 2011[1960]. The Constitution of Liberty. Chicago: University of Chicago Press.

Parsons, Talcott. 1971. The System of Modern Societies. Englewood Cliffs, NJ: Prentice-Hall.

Ronen, Shamir. 2008. "The Age of Responsibilization: On Market-Embedded Morality." Economy and Society 37 (1): 1-19.

Rose, Nikolas. 1996. Inventing Our Selves: Psychology, Power and Personhood. Cambridge: Cambridge University Press.

Rostow, Walter W. 1960. The Stages of Economic Growth. Cambridge: Cambridge University Press. 
Alessandro Bonanno and Lawrence Busch - 9781782548263 Downloaded from PubFactory at 04/26/2023 03: 02:42PM 